\title{
Melatonin and its use in atherosclerosis and dyslipidemia
}

\author{
This article was published in the following Dove Press journal: \\ ChronoPhysiology and Therapy \\ 15 March 2013 \\ Number of times this article has been viewed
}

\section{Konstantin V Danilenko Yulia I Ragino}

Institute of Internal Medicine, Siberian Branch of the Russian Academy of Medical Sciences, Novosibirsk, Russia
Correspondence: Konstantin V Danilenko Institute of Internal Medicine SB RAMS, Bogatkova 175/I, Novosibirsk 630089, Russia

Tel +73832642516

Fax +738 32642516

Email kvdani@mail.ru

\begin{abstract}
A review of pineal melatonin synthesis, regulation, and physiological effects indicates that not only does melatonin act as a hormonal signal of darkness, but also that it possesses antioxidant and anti-inflammatory properties. Although oxidation and inflammation play a pivotal role in atherogenesis, no studies have investigated administration of melatonin for human arterial atherosclerosis. However, 13 clinical trials have investigated use of melatonin in dyslipidemia, which is a close correlate of atherosclerosis. The results of these clinical trials, particularly the five that are placebo-controlled, are inconclusive as to whether melatonin can normalize the blood lipid profile. Significant confounders in these studies might be a phase shift of the cholesterol rhythm by melatonin, a posture effect at venipuncture, uncontrolled diet during the course of melatonin intake, and the phenomenon of regression to the mean. Thus, future studies are required, which should also consider use of higher doses of melatonin and/or measurement of oxidized forms of cholesterol-containing particles (which are the most aggressive in relation to atherogenesis) in addition to lipidic fractions.
\end{abstract}

Keywords: melatonin, serum lipids, atherosclerosis, clinical trials

\section{Introduction}

This review addresses questions about melatonin which have arisen in discussions with clinicians and nonspecialists. In particular, it addresses the issue of whether melatonin is indeed protective against atherosclerosis, by reviewing the available clinical studies. This review is written primarily for clinicians, and was originally published in a local Russian journal in June 2012. ${ }^{1}$ However, it has been extended to include four additional clinical trials, a summary table, and revised references (usually an initial hallmark publication and/or a review publication with the most comprehensive list of references on the topic).

\section{Melatonin content in the human body}

Melatonin is a small molecule that is synthesized consecutively from the essential amino acids tryptophan and serotonin. ${ }^{2}$ To some extent, melatonin and serotonin are antagonists, eg, serotonin can provoke vasoconstriction whereas melatonin induces vasodilation. Melatonin is not to be biochemically mistaken for melanin, which is a melanophore pigment synthesized from tyrosine for protection of the body (in particular skin) against DNA damage by ultraviolet light. The hormone and pigment are linked functionally, and the name "melatonin" (ie, "melanophore-contracting hormone") was given in 1958 by Lerner et al who first isolated the substance using a bioassay, whereby melatonin transiently lightens frog skin by inhibiting the darkening effect of 
hypophyseal melanocyte-stimulating hormone (intermedin). ${ }^{3}$ However, in higher order species, the melatonin-lightening effect is weakened; melatonin decreases melanin levels by lowering $\alpha$-intermedin secretion in fur-producing animals, but has not been found to influence melanin content in humans. $^{4}$

Melatonin is detectable in every human tissue and organ. The greatest content is in the gut, where it is synthesized for para-autocrine and autocrine action. 5,6 The endocrine effect is due to its secretion into the bloodstream from the pineal gland (epiphysis), situated in the brain caudally from the hypothalamus and hypophysis. Melatonin secretion is the only known function of the pineal gland. Pineal melatonin is synthesized and released immediately during the dark period of the day in both diurnal and nocturnal animals, thereby acting as a biochemical transducer of day-night information in the body. ${ }^{7}$ Being soluble in lipids and water, ${ }^{8,9}$ and of small molecular weight, melatonin spreads rapidly into all fluids in the organism. During the daytime, there is practically no serotonin conversion into melatonin in the pineal gland. However, night-time elevation of melatonin in body fluids is not necessarily accompanied by its increase in cells. ${ }^{10}$

Melatonin is contained in many foods, predominantly those of plant origin, eg, cereals, grapes, and tomatoes ${ }^{11}$ (see summary table in the paper by Bonnefont-Rousselot and Collin). ${ }^{12}$ The highest levels (up to $13 \mathrm{ng} / \mathrm{g}$ ) have been found in a variety of cherry. ${ }^{13}$ In cow's milk in winter, the amount is not very high, up to $0.03 \mathrm{ng} / \mathrm{mL},{ }^{14}$ and in beer is approximately $0.1 \mathrm{ng} / \mathrm{mL} .{ }^{15}$ In order to attain a significant increase of melatonin in the blood, one should consume, according to calculations, about $1 \mathrm{~kg}$ of cherries, which corresponds to a melatonin intake of $13 \mu \mathrm{g}$. This would increase its concentration in the blood up to $40 \mathrm{pg} / \mathrm{mL}$ (in comparison with normal night-time values of 25-80 (up to 200) $\mathrm{pg} / \mathrm{mL}$ compared with daytime values $<3 \mathrm{pg} / \mathrm{mL}) .{ }^{16}$ In fact, cherry concentrate, containing $85 \mu \mathrm{g}$ of melatonin, increased 6-sulphatoximelatonin levels in urine by $17 \% .{ }^{17}$ Drinking $400 \mathrm{~mL}$ per day of a "stabilized" grape juice also elevated the 6-sulphatoximelatonin concentration in urine. ${ }^{18}$ Serum melatonin is rapidly hydroxylated to 6-sulphatoximelatonin in the liver, is excreted by the kidneys, and has a half-life of approximately 30 minutes. $^{19}$

\section{Regulation of melatonin secretion}

Similar to hypothalamic neurohormones, melatonin secretion is exclusively neural-dependent. The polysynaptic pathway begins with the retinohypothalamic tract leading directly to the suprachiasmatic nuclei of the hypothalamus, descends in the medial tract of the cervical cord, enters the superior cervical ganglion, returns to the spinal cord, and projects to the pineal gland. In persons with a transverse cut of the spinal cord at a cervical level (tetraplegia), melatonin secretion is absent (whereas secretion of thyrotropin and cortisol persists). ${ }^{20}$ Some medications, especially some blockers of $\beta_{1}$ and $\alpha_{1}$ adrenoreceptors, suppress melatonin secretion. ${ }^{21}$ In darkness or under dim ambient light $(<10$ lux, just sufficient to read freely), the 24-hour variations in melatonin secretion persist because the suprachiasmatic nuclei (the "biological clock") exhibit genetically-based, endogenous circadian rhythms of neuronal activity (ie, pacemaker properties). ${ }^{22}$

Light intensity of 10-100 lux (normal room level) acting via the eyes has some effect in suppressing nocturnal melatonin production, but higher levels are required to suppress it completely. ${ }^{23,24}$ This suppression is mediated by recently discovered melanopsin photoreceptors which are sensitive to blue light (wavelength about $480 \mathrm{~nm}$, excitation), and which transmit impulses via the retinohypothalamic tract to the suprachiasmatic nuclei. These photoreceptors also transmit other biological effects of light, ie, shift of circadian rhythms, pupillary light reflex, and activation of the sympathetic nervous system, ${ }^{25}$ with a partial contribution of retinal rods and cones to these so-called "nonvisual" effects of light. In vertebrates with thin cranial bones (birds, for example), melatonin suppression may occur due to a direct action of light on pinealocytes, because some of them retain similar opsin-based photopigments. ${ }^{26}$

With the exception of light and some medications, no other interventions, including temperature, food intake, sleep, physical load, stress, or electromagnetic fields, impact significantly on melatonin secretion. A change in posture only nonspecifically influences the levels of melatonin, along with other substances in blood or saliva, changing the concentration by $10 \%-12 \%$ over 20 minutes, which is caused by redistribution of fluid between the interstitial space and the bloodstream. ${ }^{27}$ Taking into account the steadiness and distinct nature of the circadian rhythm, measurement of melatonin in saliva or serum is considered to be the most reliable "hand" of the biological clock in humans. ${ }^{28,29}$ Endogenous and exogenous melatonin do not significantly influence central regulation of melatonin secretion levels, ${ }^{30}$ despite the fact that the retina and suprachiasmatic nuclei contain a high concentration of melatonin receptors. ${ }^{31}$

\section{Functions of melatonin}

Nocturnally secreted melatonin, together with pulsatile surges of adrenocorticotropic hormone secretion during the day, ${ }^{32-34}$ is considered to synchronize body physiology at the cellular 
level, influencing expression of biological clock genes. ${ }^{35}$ Synchronization to the 24-hour day, both internal (within the body) and external (to the light-dark cycle), is the major role of pineal melatonin in all species. Exogenous melatonin is thus used to minimize jet lag and synchronize other circadian rhythm disorders, particularly in blind subjects. ${ }^{36}$ Another important role of melatonin is to transduce day length, thus signaling time of year in seasonal animals (reproduction, hibernation) and, to a lesser extent, in humans. . $^{37,38}$

The other effect of melatonin, which is somewhat related to the regulation of circadian rhythmicity, is to promote sleep onset. ${ }^{39,40}$ One of the mechanisms involves a binding with melatonin receptors in arteriovenous anastomoses in the hands and feet, leading to capillary dilatation and heat loss, with a resulting decrease in core body temperature. Distal vasodilatation favors falling asleep. ${ }^{41}$ In contrast with many sleep medications, exogenous melatonin has little effect on sleep architecture, is almost lacking in side effects, and is recommended as a first-line medication for insomnia (in a prolongedrelease form) in patients aged 55 years and older. ${ }^{42}$

Melatonin significantly influences gonadotrophin and sexual function in animals ${ }^{43}$ and may possibly play a role during puberty (eg, hypogonadism in children with melatonin hypersecretion due to a pineal tumor), ${ }^{44}$ although little is otherwise known. ${ }^{45,46}$ Other properties of melatonin include a mild reduction in blood pressure, ${ }^{47,48}$ and antioxidative ${ }^{12,49,50}$ and anti-inflammatory ${ }^{51,52}$ effects; the latter two are considered to influence cancer growth and life span, ${ }^{53,54}$ and have a beneficial effect in several pathological conditions. ${ }^{55}$

The absence of melatonin secretion is not a life-threatening state, in contrast with some other hormonal deficiencies. The amount of melatonin secreted diminishes with age because of a lowering of the mass and calcification of the pineal gland. ${ }^{56}$ It is not the absolute amount of melatonin (which covers a wide range interindividually $)^{57,58}$ but rather its decline in the individual that causes worse sleep ${ }^{56}$ and probably other health-related problems. It has been shown experimentally that humans in modern society secrete $12.5 \%$ less melatonin because of use of artificial light in the early night. ${ }^{59}$

\section{Clinical effects of melatonin on atherosclerosis and lipids}

Oxidation and inflammation are key components of atherogenesis. ${ }^{60}$ Dyslipidemia is a well established risk factor for progression of atherosclerosis, with the risk being lower when blood levels of high-density lipoprotein (HDL) cholesterol are higher, and levels of low-density lipoprotein (LDL, "bad") cholesterol and triglycerides are lower. ${ }^{61}$
When the total cholesterol level is above normal, it usually reflects increased levels of LDL cholesterol. Oxidized LDL particles play a significant role in atherogenesis. ${ }^{60}$

Melatonin has antioxidative and anti-inflammatory properties. ${ }^{12,49-52}$ As distinct from such recognized endogenous antioxidants as $\beta$-carotene and vitamins $\mathrm{E}$ and $\mathrm{C}$, melatonin does not undergo an enzymatic pathway of reduction after oxidation (redox cycling), but binds irreversibly to free radicals, and these compounds are removed by the kidneys. Not only melatonin but also precursors of its synthesis and products of its metabolism (eg, tryptophan, serotonin, 6-sulphatoxymelatonin) are able to reduce oxidative reactions, causing oxidative stress by direct free radical scavenging and indirect antioxidant activity. However, melatonin can be considered most favorable for use because of its ready passage into all cells, with excellent safety and tolerability.

A search for studies of the effects of melatonin on atherosclerosis and lipids was performed in the PubMed database (http://www.pubmed.org) using the key words "melatonin, atherosclerosis, human" and "melatonin, lipid, human". References mentioned in relevant review articles were also considered. In addition, clinical studies of melatonin were searched for in the international register, http://www.clinicaltrials.gov.

\section{Effect of melatonin on atherosclerosis}

No studies were found of melatonin in the treatment of human atherosclerosis, and only three were found in animals. In two studies, supplementation of melatonin or its related compound, DTBHB (N-[2-(5-methoxy-1H-indol-3-yl)ethyl]3,5-di-tert-butyl-4-hydroxybenzamide) to an atherogenic diet in mice with genetic hypercholesterolemia, compared with melatonin-free mice, led to a spreading or no significant change in atherosclerotic lesions of the aorta, despite clear inhibition of lipoprotein oxidation by these substances in vitro. ${ }^{62,63}$ The opposite was found in the third study, in that long-term intake of melatonin by genetically hypercholesterolemic rats hindered development of subendothelial fatty streaks formed by foam and mononuclear cells in the carotid artery, corresponding to an early stage of atherogenesis. ${ }^{64}$

\section{Effect of melatonin on lipids}

Several animal studies have demonstrated an effect of melatonin on lipids. For example, an infusion of melatonin to genetically hypercholesterolemic rats decreased cholesterol levels in plasma and favored an involution of steatohepatosis, ${ }^{65}$ although the cholesterol decrease may have been related to greater renal excretion. ${ }^{66}$ In rats fed fructose, 
which causes changes characteristic of the metabolic syndrome, melatonin attenuated deterioration of the lipid blood profile in a dose-dependent manner. ${ }^{67}$ Two different dose levels of melatonin significantly decreased lipid peroxidation and levels of cholesterol, phospholipids, triglycerides, and free fatty acids in rat brain and liver. ${ }^{68}$ In another study performed in normally fed rats, all lipid indices remained unchanged, but there was an increase in long-chain n-6 polyunsaturated fatty acids in total plasma lipids and liver phospholipids. ${ }^{64}$ More on the effects of melatonin on lipids in animals is summarized in a recent review. ${ }^{69}$

Eight open-label clinical studies in humans were identified (Table 1). Melatonin was usually administered in the evening. Pittalis et al gave $10 \mathrm{mg}$ melatonin for one month to 14

Table I Clinical studies of the effects of melatonin on lipids

\begin{tabular}{|c|c|c|c|c|c|}
\hline Study & Subjects completed & $\begin{array}{l}\text { Melatonin dose, time of } \\
\text { day, and duration }\end{array}$ & Initial lipid levels & Results & $\begin{array}{l}\text { Possible } \\
\text { confounder }\end{array}$ \\
\hline \multicolumn{6}{|c|}{ Open trials (no placebo control for melatonin) } \\
\hline $\begin{array}{l}\text { Pittalis } \\
\text { et al }{ }^{70}\end{array}$ & $\begin{array}{l}\text { I4 patients with } \\
\text { idiopathic } \\
\text { hypercholesterolemia }\end{array}$ & $\begin{array}{l}10 \mathrm{mg} \text { "during the evening" } \\
\text { for I month }\end{array}$ & $\begin{array}{l}\mathrm{TC}>200 \mathrm{mg} / \mathrm{dL} \\
\mathrm{HDL} \text { and } \mathrm{Tg}-\text { intermediate } \\
\text { mean levels }\end{array}$ & $\begin{array}{l}\mathrm{HDL} \uparrow \\
\mathrm{TC}, \mathrm{Tg}=\end{array}$ & \\
\hline $\begin{array}{l}\text { Wakatsuki } \\
\text { et } \mathrm{al}^{71,72}\end{array}$ & $\begin{array}{l}\text { I5 normolipidemic } \\
\text { postmenopausal women }\end{array}$ & $\begin{array}{l}6 \mathrm{mg} \text { between } 9 \mathrm{pm} \text { and } \\
10 \mathrm{pm} \text { for } 2 \text { weeks }\end{array}$ & $\begin{array}{l}\mathrm{TC}<220 \mathrm{mg} / \mathrm{dL} \\
\mathrm{Tg}<150 \mathrm{mg} / \mathrm{dL} \\
\mathrm{LDL}, \mathrm{HDL}-\text { optimal } \\
\text { mean levels }\end{array}$ & $\begin{array}{l}\text { VLDL, Tg, VLDL-Tg } \uparrow \\
\text { TC, LDL, HDL = }\end{array}$ & $\begin{array}{l}\text { Regression to } \\
\text { the mean }\end{array}$ \\
\hline $\begin{array}{l}\text { Pawlikowski } \\
\text { et } \mathrm{al}^{73}\end{array}$ & 14 elderly women & $6 \mathrm{mg}$ at $7 \mathrm{pm}$ for 6 months & $\begin{array}{l}\mathrm{TC}, \mathrm{LDL} \text { - intermediate, } \\
\mathrm{HDL}, \mathrm{Tg} \text { - optimal mean levels }\end{array}$ & $\mathrm{TC}, \mathrm{LDL}, \mathrm{HDL}, \mathrm{Tg}=$ & $\begin{array}{l}\text { Circadian } \\
\text { phase advance }\end{array}$ \\
\hline $\begin{array}{l}\text { Tamura } \\
\text { et al }{ }^{74}\end{array}$ & $\begin{array}{l}\text { I0 perimenopausal } \\
\text { and postmenopausal } \\
\text { women }\end{array}$ & I $\mathrm{mg}$ at $9 \mathrm{pm}$ for I month & $\begin{array}{l}\mathrm{TC}, \mathrm{LDL}, \mathrm{HDL} \text { - intermediate, } \\
\mathrm{Tg} \text { - normal mean levels }\end{array}$ & $\begin{array}{l}\mathrm{HDL} \uparrow \\
\mathrm{TC}, \mathrm{LDL}, \mathrm{Tg}=\end{array}$ & \\
\hline $\begin{array}{l}\text { Kadhim } \\
\text { et } \mathrm{al}^{75}\end{array}$ & $\begin{array}{l}18 \text { versus } 15 \text { type } 2 \\
\text { diabetic patients } \\
\text { receiving metformin }\end{array}$ & $\begin{array}{l}10 \mathrm{mg} \text { ( }+50 \mathrm{mg} \text { zinc acetate) } \\
\text { versus placebo at bedtime } \\
\text { for } 3 \text { months }\end{array}$ & $\begin{array}{l}\mathrm{TC}, \mathrm{LDL} \text { - normal or higher, } \\
\mathrm{HDL} \text { - normal, } \mathrm{Tg} \text { - higher } \\
\text { versus healthy controls }\end{array}$ & $\mathrm{TC}, \mathrm{LDL}, \mathrm{Tg} \downarrow, \mathrm{HDL} \uparrow$ & $\begin{array}{l}\text { Regression to } \\
\text { the mean }\end{array}$ \\
\hline $\begin{array}{l}\text { Koziróg } \\
\text { et al }{ }^{76}\end{array}$ & $\begin{array}{l}30 \text { subjects with } \\
\text { metabolic syndrome }\end{array}$ & $\begin{array}{l}5 \mathrm{mg} \text { before bedtime } \\
\text { for } 2 \text { months }\end{array}$ & $\begin{array}{l}\mathrm{TC}, \mathrm{LDL}, \mathrm{Tg} \text { - higher, } \\
\mathrm{HDL}-\text { lower versus healthy } \\
\text { controls, intermediate } \\
\text { mean levels }\end{array}$ & $\begin{array}{l}\mathrm{LDL} \downarrow \\
\mathrm{TC}, \mathrm{HDL}, \mathrm{Tg}=\end{array}$ & $\begin{array}{l}\text { Regression to } \\
\text { the mean }\end{array}$ \\
\hline $\begin{array}{l}\text { Korkushko } \\
\text { et } \mathrm{al}^{77}\end{array}$ & $\begin{array}{l}39 \text { elderly versus } 40 \text { free- } \\
\text { medicated elderly, } \\
\text { with low melatonin levels }\end{array}$ & $\begin{array}{l}5 \text { injections of epithalamin } \\
\text { during a } 15 \text {-day treatment } \\
\text { course, and } 6 \text { courses of } \\
\text { treatment } \\
\text { half-yearly over } 3 \text { years }\end{array}$ & $\begin{array}{l}\text { TC }- \text { unspecified } \\
\text { LDL }- \text { high mean levels }\end{array}$ & TC, LDL $\downarrow$ & \\
\hline $\begin{array}{l}\text { Shatilo } \\
\text { et al }{ }^{78}\end{array}$ & 30 elderly hypertensives & $\begin{array}{l}\text { I.5-3 mg at } 9 \mathrm{pm} \\
\text { (+lisinopril or amlodipine) } \\
\text { for } 4 \text { weeks }\end{array}$ & $\begin{array}{l}\mathrm{TC}, \mathrm{LDL}, \mathrm{HDL} \text { - intermediate, } \\
\mathrm{Tg} \text { - optimal mean levels }\end{array}$ & $\begin{array}{l}\text { TC, LDL } \downarrow \text { (in a subgroup with } \\
\text { initially higher levels of TC) } \\
\text { VLDL, HDL, Tg = }\end{array}$ & $\begin{array}{l}\text { Regression to } \\
\text { the mean }\end{array}$ \\
\hline \multicolumn{6}{|c|}{ Placebo-controlled trials } \\
\hline $\begin{array}{l}\text { Rindone and } \\
\text { Achacoso }^{79}\end{array}$ & $\begin{array}{l}16 \text { hypercholesterolemic } \\
\text { patients; crossover study }\end{array}$ & $\begin{array}{l}0.3 \mathrm{mg}, 3 \mathrm{mg} \text {, placebo } \\
\text { at bedtime for } 6 \text { weeks } \\
\text { each }\end{array}$ & $\begin{array}{l}\mathrm{LDL}>160 \mathrm{mg} / \mathrm{dL} \\
\mathrm{TC}, \mathrm{LDL}, \mathrm{Tg}-\text { high, } \\
\mathrm{HDL}-\text { intermediate } \\
\text { mean levels }\end{array}$ & $\mathrm{TC}, \mathrm{LDL}, \mathrm{HDL}, \mathrm{Tg}=$ & \\
\hline $\begin{array}{l}\text { Seabra } \\
\text { et al }{ }^{80}\end{array}$ & $\begin{array}{l}30 \text { versus } 10 \text { healthy } \\
\text { subjects }\end{array}$ & $\begin{array}{l}10 \mathrm{mg} \text { versus placebo I hour } \\
\text { before bedtime for I month }\end{array}$ & $\begin{array}{l}\mathrm{TC}, \mathrm{LDL}, \mathrm{HDL} \text { - intermediate, } \\
\mathrm{Tg} \text { - optimal mean levels }\end{array}$ & $\begin{array}{l}\text { TC, LDL, HDL, } \\
\text { VLDL, } T g=\end{array}$ & \\
\hline $\begin{array}{l}\text { Cichoz-Lach } \\
\text { et al }{ }^{84}\end{array}$ & $\begin{array}{l}\text { I5 versus } 15 \text { patients } \\
\text { with nonalcoholic } \\
\text { fatty hepatosis }\end{array}$ & $\begin{array}{l}5 \text { mg versus placebo twice } \\
\text { daily (+Essentiale Forte*) } \\
\text { for I month }\end{array}$ & $\begin{array}{l}\text { TC - high-to-intermediate, } \\
\mathrm{LDL}, \mathrm{Tg} \text { - high, } \\
\mathrm{HDL}-\text { low mean levels }\end{array}$ & $\begin{array}{l}\mathrm{Tg} \downarrow \\
\mathrm{TC}, \mathrm{LDL}, \mathrm{HDL}=\end{array}$ & $\begin{array}{l}\text { Regression to } \\
\text { the mean }\end{array}$ \\
\hline $\begin{array}{l}\text { Gonciarz } \\
\text { et } \mathrm{al}^{82,83}\end{array}$ & $\begin{array}{l}30 \text { versus } 12 \text { patients } \\
\text { with nonalcoholic } \\
\text { fatty hepatosis }\end{array}$ & $\begin{array}{l}5 \mathrm{mg} \text { versus placebo at } 9 \text { am } \\
\text { and } 9 \mathrm{pm} \text { for } 6 \text { months }+ \\
\text { follow-up in } 3 \text { months }\end{array}$ & $\begin{array}{l}\mathrm{TC}, \mathrm{Tg} \text { - intermediate- } \\
\text { to-optimal mean levels }\end{array}$ & $\mathrm{TC}, \mathrm{Tg}=$ & \\
\hline $\begin{array}{l}\text { Garfinkel } \\
\text { et } \mathrm{al}^{81}\end{array}$ & $\begin{array}{l}36 \text { type } 2 \text { diabetic } \\
\text { patients with insomnia; } \\
\text { crossover study }\end{array}$ & $\begin{array}{l}2 \mathrm{mg} \text { (prolonged-release), } \\
\text { placebo } 2 \text { hours before } \\
\text { bedtime for } 3 \text { weeks each }\end{array}$ & Unspecified & $\mathrm{TC}, \mathrm{LDL}, \mathrm{HDL}, \mathrm{Tg}=$ & \\
\hline
\end{tabular}

Notes: *Essentiale Forte, compound containing natural "essential" phospholipids (diglyceride esters of cholinephosphoric acid) enriched with unsaturated fatty acids, vitamins $\mathrm{BI}, \mathrm{B} 2, \mathrm{~B} 6, \mathrm{BI}$, E, and nicotinamide.

Abbreviations: TC, total cholesterol (intermediate levels, 200-240 mg/dL); LDL, low-density lipoprotein cholesterol (100-160 mg/dL); HDL, high-density lipoprotein cholesterol (40-59 mg/dL for men, 50-60 mg/dL for women); Tg, triglycerides ( $150-200 \mathrm{mg} / \mathrm{dL}$ ); VLDL, very-low-density lipoprotein cholesterol; =, no change; $\downarrow$, decrease; $\uparrow$, increase. 
patients with idiopathic hypercholesterolemia and found an improvement in lipid concentrations, which were significant for HDL cholesterol. ${ }^{70}$ In a study of 15 normolipidemic postmenopausal women who took $6 \mathrm{mg}$ of melatonin for 2 weeks, triglyceride and very-LDL (VLDL) cholesterol levels deteriorated. ${ }^{71,72}$ In another group comprising 14 elderly women who took melatonin daily for 6 months, the serum lipid profile did not change. ${ }^{73}$ In a fourth study, 10 perimenopausal and postmenopausal women received $1 \mathrm{mg}$ of melatonin for a month, and an elevation of HDL cholesterol was observed. ${ }^{74}$ In a fifth study, 33 patients with type 2 diabetes showed improvement in their lipid profile after 3 months of treatment with melatonin and zinc acetate compared with placebo, ${ }^{75}$ but whether this was due to melatonin alone is not clear. In a sixth study, LDL cholesterol levels decreased following 2 months of treatment with melatonin in 30 subjects with metabolic syndrome, together with an improvement in the antioxidant properties of blood in vitro. ${ }^{76}$ In a seventh study, six courses of intramuscular injections of the pineal extract, epithalamin, given at a 6-monthly interval over 3 years, resulted in an increased night-time plasma concentration of melatonin, a decrease in total and LDL cholesterol, and a deceleration of cardiovascular aging in 39 elderly subjects as compared with 40 controls. ${ }^{77}$ In an eighth study of elderly hypertensives with increased total cholesterol levels, both total and LDL cholesterol levels were reduced following 2 or 4 weeks of melatonin administration at 9 pm. ${ }^{78}$ However, this result might have been attributable to the regression towards the mean phenomenon (see below).

Five placebo-controlled clinical studies were identified (Table 1). In four studies, no change in the blood lipid profile was found. According to Rindone and Achacoso, there was no change in the lipid profiles of 16 subjects with hypercholesterolemia following administration of placebo, melatonin $0.3 \mathrm{mg}$, or melatonin $3 \mathrm{mg}$, each given in a random order. ${ }^{79} \mathrm{~A}$ similar result was obtained in 30 healthy individuals after a month of taking melatonin $10 \mathrm{mg}$ as compared with a group receiving placebo. ${ }^{80} \mathrm{In} 36$ patients with type 2 diabetes, intake of prolonged-release melatonin or placebo for 3 weeks did not change total, LDL, and HDL cholesterol, or triglyceride concentrations. ${ }^{81}$ In 30 patients with nonalcoholic fatty liver disease, treatment with melatonin for 6 months also had no effect on cholesterol and triglyceride levels, nor were these levels changed 3 months after discontinuation of melatonin, compared with a group of 12 patients receiving placebo. ${ }^{82,83}$ However, in another study of 15 patients with nonalcoholic steatohepatosis who took Essentiale Forte ${ }^{\circledR}$ (Aventis, Bridgewater, NJ) and melatonin for one month, there was a decrease in levels of triglycerides and anti-inflammatory cytokines, as compared with 15 patients who received Essentiale Forte and placebo. ${ }^{84}$

In addition, in a nonclinical study of the immediate effect of melatonin in football players, serum concentrations of triglycerides and peroxidized lipids were found to be lower following physical training if $6 \mathrm{mg}$ of melatonin was taken in advance, compared with a placebo group. ${ }^{85}$

Regression to the mean might confound the results of some open clinical studies. The regression to the mean phenomenon postulates that abnormal initial values tend to shift automatically towards the population norm at remeasurement, without any specific interventions. For example, a high mean cholesterol level of $6.98 \mathrm{mmol} / \mathrm{L}$ might be expected to decrease to $6.40 \mathrm{mmol} / \mathrm{L}$ on re-examination. ${ }^{86}$ In fact, three of the eight open clinical studies, in which initial levels of total cholesterol, LDL cholesterol, and/or triglycerides were high (or higher than in control subjects), ${ }^{75,76,78}$ reported a decrease after treatment with melatonin (Table 1). In contrast, an unfavorable increase in triglycerides was reported for a study in which the concentration was initially low (optimal) according to inclusion criteria..$^{71,72}$

Placebo control is the gold standard in evidence-based medicine. The majority of the placebo-controlled studies showed no effect of melatonin on the lipid profile (Table 1). Only one of the five studies documented a change (a decrease in triglyceride levels), ${ }^{84}$ but placebo was not adequately defined in the methods section of the paper (nor clarified via emails by the authors) to estimate the validity of this change.

Melatonin administered $\geq 2$ hours before the normal bedtime may phase advance the circadian system. ${ }^{87}$ If this is the case, cholesterol levels, which rise in the morning, ${ }^{88}$ would appear higher on remeasurement at the same time in the morning, masking the possible beneficial effect of melatonin. A posture-confounding effect (mechanism described above) on serum lipid concentrations upon morning venipuncture should also be considered ${ }^{89}$ Further, the effect of melatonin on the lipid profile may be too modest to be revealed over the masking effect of diet, which was usually not controlled for in the clinical studies. The degree of oxidation of LDL particles would probably be a better index of the effect of melatonin than lipid concentrations. ${ }^{85,90,91}$ Further, it is likely that only very high supraphysiological doses of melatonin could demonstrate an antioxidant effect in vivo. ${ }^{10}$

\section{Correlation between endogenous melatonin and lipids}

In two studies, night-time melatonin levels were found to correlate positively with HDL cholesterol levels and negatively 
with total and LDL cholesterol levels. ${ }^{74,92}$ However, a study by Masue et al did not reveal a significant correlation between the morning amount of urinary 6-sulfatoxymelatonin and plasma lipid concentrations in 181 women. ${ }^{93}$ In 24 patients suffering from multiple sclerosis, a subgroup with low levels of nocturnal plasma melatonin had higher serum total cholesterol concentrations than those in a subgroup with normal plasma melatonin levels. ${ }^{94}$ In 60 patients with acute myocardial infarction ${ }^{90}$ and in 21 patients suffering from unstable angina, ${ }^{91}$ night-time melatonin levels were decreased compared with controls and associated with elevated oxidized serum LDL levels. The latter and similar studies (reviewed in DominguezRodriguez et al $)^{95}$ triggered the design of two clinical studies of the efficacy of intravascular injections of melatonin during angioplasty for limitation of ischemia-reperfusion injury in patients with acute myocardial infarction (http://www. clinicaltrials.gov, NCT00640094 and NCT01172171).

\section{Conclusion}

No studies demonstrating an effect of melatonin on arterial atherosclerosis in humans have been found. There are studies of the influence of melatonin on the serum lipid profile (a close correlate of atherosclerosis), but the results are ambiguous, in that the majority of open trials (six of eight) reported improvement in lipid indices following treatment with melatonin, whereas the majority of placebocontrolled studies (four of five) found no significant effect. This ambiguity may be partly attributable to methodological limitations. Nevertheless, considering the antioxidative and anti-inflammatory properties of melatonin, and also correlations between levels of endogenous melatonin and lipids in the blood, further studies are warranted, given that oxidation and inflammation play a pivotal role in atherogenesis.

\section{Acknowledgment}

The authors thank Anna Wirz-Justice for her English editing and comments on the manuscript.

\section{Disclosure}

The authors report no conflicts of interest in this work.

\section{References}

1. Danilenko KV. Melatonin, serum lipids, and atherosclerosis: a review of clinical studies. Atherosclerosis. 2012;8:18-24. Russian.

2. Claustrat B, Brun J, Chazot G. The basic physiology and pathophysiology of melatonin. Sleep Med Rev. 2005;9:11-24.

3. Lerner AB, Case JD, Takahashi Y, Lee TH, Mori N. Isolation of melatonin, the pineal gland factor that lightens melanocytes. JAm Chem Soc. 1958;80:2587-2589.

4. Cohn BA. Melatonin and the skin: from frog to human. Int J Dermatol. 1996;35:695-697.
5. Kvetnoy IM, Ingel IE, Kvetnaia TV, et al. Gastrointestinal melatonin: cellular identification and biological role. Neuro Endocrinol Lett. 2002;23:121-132.

6. Bubenik GA. Thirty four years since the discovery of gastrointestinal melatonin. J Physiol Pharmacol. 2008;59 Suppl 2:33-51.

7. Stehle JH, Saade A, Rawashdeh O, et al. A survey of molecular details in the human pineal gland in the light of phylogeny, structure, function and chronobiological diseases. J Pineal Res. 2011;51:17-43.

8. Costa EJX, Shida CS, Biaggi MH, Ito AS, Lamy-Freund MT. How melatonin interacts with lipid bilayers: a study by fluorescence and ESR spectroscopies. FEBS Lett. 1997;416:103-106.

9. Shida CS, Castrucci AML, Lamy-Freund MT. High melatonin solubility in aqueous medium. J Pineal Res. 1994;16:198-201.

10. Venegas C, García JA, Escames G, et al. Extrapineal melatonin: analysis of its subcellular distribution and daily fluctuations. $J$ Pineal Res. 2012;52:217-227.

11. Iriti M, Varoni EM, Vitalini S. Melatonin in traditional Mediterranean diets. J Pineal Res. 2010;49:101-105.

12. Bonnefont-Rousselot D, Collin F. Melatonin: action as antioxidant and potential applications in human disease and aging. Toxicology. 2010;278:55-67.

13. Burkhardt S, Tan DX, Manchester LC, Hardeland R, Reiter RJ. Detection and quantification of the antioxidant melatonin in Montmorency and Balaton tart cherries (Prunus cerasus). J Agric Food Chem. 2001;49:4898-4902.

14. Eriksson L, Valtonen M, Laitinen JT, Paananen M, Kaikkonen M. Diurnal rhythm of melatonin in bovine milk: pharmacokinetics of exogenous melatonin in lactating cows and goats. Acta Vet Scand. 1998;39:301-310.

15. Maldonado MD, Moreno H, Calvo JR. Melatonin present in beer contributes to increase the levels of melatonin and antioxidant capacity of the human serum. Clin Nutr. 2009;28:188-191.

16. Lewy AJ, Emens JS, Lefler BJ, Yuhas K, Jackman AR. Melatonin entrains free-running blind people according to a physiological doseresponse curve. Chronobiol Int. 2005;22:1093-1106.

17. Howatson G, Bell PG, Tallent J, Middleton B, McHugh MP, Ellis J. Effect of tart cherry juice (Prunus cerasus) on melatonin levels and enhanced sleep quality. Eur J Nutr. 2012;51:909-916.

18. González-Flores D, Gamero E, Garrido M, et al. Urinary 6-sulfatoxymelatonin and total antioxidant capacity increase after the intake of a grape juice cv. Tempranillo stabilized with HHP. Food Funct. 2012;3:34-39.

19. Geoffriau M, Claustrat B, Veldhuis J. Estimation of frequently sampled nocturnal melatonin production in humans by deconvolution analysis: evidence for episodic or ultradian secretion. J Pineal Res. 1999;27:139-144.

20. Zeitzer JM, Ayas NT, Shea SA, Brown R, Czeisler CA. Absence of detectable melatonin and preservation of cortisol and thyrotropin rhythms in tetraplegia. J Clin Endocrinol Metab. 2000;85: 2189-2196.

21. Stoschitzky K, Sakotnik A, Lercher P, et al. Influence of beta-blockers on melatonin release. Eur J Clin Pharmacol. 1999;55:111-115.

22. Weaver DR. The suprachiasmatic nucleus: a 25-y retrospective. J Biol Rhythms. 1998;13:100-112.

23. Gaddy JR, Rollag MD, Brainard GC. Pupil size regulation of threshold of light-induced melatonin suppression. J Clin Endocrinol Metab. 1993;77:1398-1401.

24. Zeitzer JM, Dijk DJ, Kronauer RE, Brown EN, Czeisler CA. Sensitivity of the human circadian pacemaker to nocturnal light: melatonin phase resetting and suppression. J Physiol (Lond). 2000;526:695-702.

25. Hatori M, Panda S. The emerging roles of melanopsin in behavioral adaptation to light. Trends Mol Med. 2010;16:435-446.

26. Holthues H, Engel L, Spessert R, Vollrath L. Circadian gene expression patterns of melanopsin and pinopsin in the chick pineal gland. Biochem Biophys Res Commun. 2005;326:160-165.

27. Deacon S, Arendt J. Posture influences melatonin concentrations in plasma and saliva in humans. Neurosci Lett. 1994;167:191-194. 
28. Klerman EB, Gershengorn HB, Duffy JF, Kronauer RE. Comparisons of the variability of three markers of the human circadian pacemaker. J Biol Rhythms. 2002;17:181-193.

29. Benloucif S, Guico MJ, Reid KJ, Wolfe LF, L'Hermite-Baleriaux M, Zee PC. Stability of melatonin and temperature as circadian phase markers and their relation to sleep times in humans. J Biol Rhythms. 2005;20:178-188

30. Rajaratnam SM, Dijk DJ, Middleton B, Stone BM, Arendt J. Melatonin phase-shifts human circadian rhythms with no evidence of changes in the duration of endogenous melatonin secretion or the 24-hour production of reproductive hormones. J Clin Endocrinol Metab. 2003;88: 4303-4309.

31. Pandi-Perumal SR, Trakht I, Srinivasan V, et al. Physiological effects of melatonin: role of melatonin receptors and signal transduction pathways. Prog Neurobiol. 2008;185:335-353.

32. Balsalobre A, Brown SA, Marcacci L, et al. Resetting of circadian time in peripheral tissues by glucocorticoid signaling. Science. 2000 ; 289:2344-2347.

33. Russell GM, Henley DE, Leendertz J, et al. Rapid glucocorticoid receptor-mediated inhibition of hypothalamic-pituitary-adrenal ultradian activity in healthy males. J Neurosci. 2010;30:6106-6115.

34. Waite EJ, McKenna M, Kershaw Y, et al. Ultradian corticosterone secretion is maintained in the absence of circadian cues. Eur J Neurosci. 2012;36:3142-3150.

35. Siepka SM, Yoo SH, Park J, Lee C, Takahashi JS. Genetics and neurobiology of circadian clocks in mammals. Cold Spring Harb Symp Quant Biol. 2007;72:251-259.

36. Zawilska JB, Skene DJ, Arendt J. Physiology and pharmacology of melatonin in relation to biological rhythms. Pharmacol Rep. 2009;61: 383-410.

37. Arendt J. Melatonin and the pineal gland: influence on mammalian seasonal and circadian physiology. Rev Reprod. 1998;3:13-22.

38. Wehr TA. Photoperiodism in humans and other primates: evidence and implications. J Biol Rhythms. 2001;16:348-364.

39. Vollrath L, Semm P, Gammel G. Sleep induction by intranasal administration of melatonin. Adv Biosci. 1981;29:327-329.

40. Cardinali DP, Vidal MF, Vigo DE. New developments in the treatment of primary insomnia in elderly patients: focus on prolonged-release melatonin. ChronoPhysiology and Therapy. 2012;2:67-79.

41. Kräuchi K, Cajochen C, Pache M, Flammer J, Wirz-Justice A Thermoregulatory effects of melatonin in relation to sleepiness. Chronobiol Int. 2006;23:475-484

42. Wilson SJ, Nutt DJ, Alford C, et al. British Association for Psychopharmacology consensus statement on evidence-based treatment of insomnia, parasomnias and circadian rhythm disorders. J Psychopharmacol. 2010;24:1577-1601.

43. Reiter RJ, Tan DX, Manchester LC, Paredes SD, Mayo JC, Sainz RM. Melatonin and reproduction revisited. Biol Reprod. 2009; 81:445-456.

44. Puig-Domingo M, Webb SM, Serrano J, et al. Brief report: melatoninrelated hypogonadotropic hypogonadism. $N$ Engl J Med. 1992;327: 1356-1359.

45. Kripke DF, Kline LE, Shadan FF, Dawson A, Poceta JS, Elliott JA Melatonin effects on luteinizing hormone in postmenopausal women a pilot clinical trial NCT00288262. BMC Womens Health. 2006;6:8.

46. Srinivasan V, Spence WD, Pandi-Perumal SR, Zakharia R, Bhatnagar KP, Brzezinski A. Melatonin and human reproduction: shedding light on the darkness hormone. Gynecol Endocrinol. 2009;25:779-785.

47. Cagnacci A, Arangino S, Angiolucci M, Maschio E, Melis GB Influences of melatonin administration on the circulation of women. Am J Physiol. 1998;274:R335-R338.

48. Grossman E, Laudon M, Zisapel N. Effect of melatonin on nocturnal blood pressure: meta-analysis of randomized controlled trials. Vasc Health Risk Manag. 2011;7:577-584.

49. Tan DX, Chen LD, Poeggeler B, Manchester LC, Reiter RJ. Melatonin: a potent, endogenous hydroxyl radical scavenger. Endocr J. 1993;1: $57-60$.
50. Galano A, Tan DX, Reiter RJ. Melatonin as a natural ally against oxidative stress: a physicochemical examination. J Pineal Res. 2011;51: $1-16$.

51. Radogna F, Diederich M, Ghibelli L. Melatonin: a pleiotropic molecule regulating inflammation. Biochem Pharmacol. 2010;80:1844-1852.

52. Mauriz JL, Collado PS, Veneroso C, Reiter RJ, González-Gallego J. A review of the molecular aspects of melatonin's anti-inflammatory actions: recent insights and new perspectives. J Pineal Res. May 31, 2012. [Epub ahead of print.]

53. Anisimov VN, Popovich IG, Zabezhinski MA, Anisimov SV, Vesnushkin GM, Vinogradova IA. Melatonin as antioxidant, geroprotector and anticarcinogen. Biochim Biophys Acta. 2006;1757: 573-589.

54. Bubenik GA, Konturek SJ. Melatonin and aging: prospects for human treatment. J Physiol Pharmacol. 2011;62:13-19.

55. Sánchez-Barceló EJ, Mediavilla MD, Tan DX, Reiter RJ. Clinical uses of melatonin: evaluation of human trials. Curr Med Chem. 2010;17: 2070-2095.

56. Kunz D, Schmitz S, Mahlberg R, et al. A new concept for melatonin deficit: on pineal calcification and melatonin excretion. Neuropsychopharmacology. 1999;21:765-672.

57. Burgess HJ, Fogg LF. Individual differences in the amount and timing of salivary melatonin secretion. PLoS One. 2008;3:e3055.

58. Verheggen RJ, Jones H, Nyakayiru J, et al. Complete absence of evening melatonin increase in tetraplegics. FASEB J. 2012;26:3059-3064.

59. Gooley JJ, Chamberlain K, Smith KA, et al. Exposure to room light before bedtime suppresses melatonin onset and shortens melatonin duration in humans. J Clin Endocrinol Metab. 2011;96:E463-E472.

60. Libby P, Ridker PM, Hansson GK. Progress and challenges in translating the biology of atherosclerosis. Nature. 2011;473:317-325.

61. Reiner Z, Catapano AL, De Backer G, Graham I, et al; European Association for Cardiovascular Prevention and Rehabilitation. ESC/ EAS Guidelines for the management of dyslipidaemias: the Task Force for the management of dyslipidaemias of the European Society of Cardiology (ESC) and the European Atherosclerosis Society (EAS). Eur Heart J. 2011;32:1769-1818.

62. Tailleux A, Torpier G, Bonnefont-Rousselot D, et al. Daily melatonin supplementation in mice increases atherosclerosis in proximal aorta. Biochem Biophys Res Commun. 2002;293:1114-1123.

63. Tailleux A, Gozzo A, Torpier G, et al. Increased susceptibility of lowdensity lipoprotein to ex vivo oxidation in mice transgenic for human apolipoprotein B treated with 1 melatonin-related compound is not associated with atherosclerosis progression. J Cardiovasc Pharmacol. 2005;46:241-249.

64. Pita ML, Hoyos M, Martin-Lacave I, Osuna C, Fernández-Santos JM, Guerrero JM. Long-term melatonin administration increases polyunsaturated fatty acid percentage in plasma lipids of hypercholesterolemic rats. J Pineal Res. 2002;32:179-186.

65. Aoyama H, Mori N, Mori W. Effects of melatonin on genetic hyper-cholesterolemia in rats. Atherosclerosis. 1988;69:269-272.

66. Tengattini S, Reiter RJ, Tan DX, Terron MP, Rodella LF, Rezzani R. Cardiovascular diseases: protective effects of melatonin. J Pineal Res. 2008;44:16-25

67. Kitagawa A, Ohta Y, Ohashi K. Melatonin improves metabolic syndrome induced by high fructose intake in rats. J Pineal Res. 2012;52 403-413.

68. Subramanian P, Mirunalini S, Pandi-Perumal SR, Trakht I, Cardinali DP. Melatonin treatment improves the antioxidant status and decreases lipid content in brain and liver of rats. Eur J Pharmacol. 2007;571:116-119.

69. Mozaffari S, Hasani-Ranjbar S, Abdollahi M. The mechanisms of positive effects of melatonin in dyslipidemia: a systematic review of animal and human studies. Int J Pharmacol. 2012;8:496-509.

70. Pittalis S, Lissoni P, Giani L, et al. Effect of a chronic therapy with the pineal hormone melatonin on cholesterol levels in idiopathic hypercholesterolemic patients. Recenti Prog Med. 1997;88:401-402. Italian 
71. Wakatsuki A, Okatani Y, Ikenoue N, Izumiya C, Kaneda C. Melatonin inhibits oxidative modification of low-density lipoprotein particles in normolipidemic post-menopausal women. J Pineal Res. 2000;28: 136-142.

72. Wakatsuki A, Okatani Y, Ikenoue N, Kaneda C, Fukaya T. Effects of short-term melatonin administration on lipoprotein metabolism in normolipidemic postmenopausal women. Maturitas. 2001;38: 171-177.

73. Pawlikowski M, Kolomecka M, Wojtczak A, Karasek M. Effects of six months melatonin treatment on sleep quality and serum concentrations of estradiol, cortisol, dehydroepiandrosterone sulfate, and somatomedin C in elderly women. Neuro Endocrinol Lett. 2002; 23 Suppl 1:17-19.

74. Tamura H, Nakamura Y, Narimatsu A, et al. Melatonin treatment in periand postmenopausal women elevates serum high-density lipoprotein cholesterol levels without influencing total cholesterol levels. J Pineal Res. 2008;45:101-105.

75. Kadhim HM, Ismail SH, Hussein KI, et al. Effects of melatonin and zinc on lipid profile and renal function in type 2 diabetic patients poorly controlled with metformin. J Pineal Res. 2006;41:189-193.

76. Koziróg M, Poliwczak AR, Duchnowicz P, Koter-Michalak M, Sikora J, Broncel M. Melatonin treatment improves blood pressure, lipid profile, and parameters of oxidative stress in patients with metabolic syndrome. J Pineal Res. 2011;50:261-266.

77. Korkushko OV, Khavinson VKH, Shatilo VB, Antonyk-Sheglova IA. Peptide geroprotector from the pituitary gland inhibits rapid aging of elderly people: results of 15-year follow-up. Bull Exp Biol Med. 2011;151:343-347.

78. Shatilo VB, Bondarenko EV, Antoniuk-Shcheglova IA. Metabolic disorders in elderly patients with hypertension and their correction with melatonin. Adv Gerontol. 2012;25:84-89. Russian.

79. Rindone JP, Achacoso R. Effect of melatonin on serum lipids in patients with hypercholesterolemia: a pilot study. Am J Ther. 1997;4: 409-411.

80. Seabra ML, Bignotto M, Pinto LR Jr, Tufik S. Randomized, doubleblind clinical trial, controlled with placebo, of the toxicology of chronic melatonin treatment. J Pineal Res. 2000;29:193-200.

81. Garfinkel D, Zorin M, Wainstein J, Matas Z, Laudon M, Zisapel N. Efficacy and safety of prolonged-release melatonin in insomnia patients with diabetes: a randomized, double-blind, crossover study. Diabetes Metab Syndr Obes. 2011;4:307-313.

82. Gonciarz M, Gonciarz Z, Bielanski W, et al. The pilot study of 3-month course of melatonin treatment of patients with nonalcoholic steatohepatitis: effect on plasma levels of liver enzymes, lipids and melatonin. J Physiol Pharmacol. 2010;61:705-710.
83. Gonciarz M, Gonciarz Z, Bielanski W, et al. The effects of longterm melatonin treatment on plasma liver enzyme levels and plasma concentrations of lipids and melatonin in patients with nonalcoholic steatohepatitis: a pilot study. J Physiol Pharmacol. 2012;63:35-40.

84. Cichoz-Lach H, Celinski K, Konturek PC, Konturek SJ, Slomka M. The effects of L-tryptophan and melatonin on selected biochemical parameters in patients with steatohepatitis. J Physiol Pharmacol. 2010; 61:577-580

85. Maldonado MD, Manfredi M, Ribas-Serna J, Garcia-Moreno H, Calvo JR. Melatonin administrated immediately before an intense exercise reverses oxidative stress, improves immunological defenses and lipid metabolism in football players. Physiol Behav. 2012;105: 1099-1103.

86. Yudkin PL, Stratton IM. How to deal with regression to the mean in intervention studies. Lancet. 1999;347:241-243.

87. Burgess HJ, Revell VL, Molina TA, Eastman CI. Human phase response curves to three days of daily melatonin: $0.5 \mathrm{mg}$ versus $3.0 \mathrm{mg}$. J Clin Endocrinol Metab. 2010;95:3325-3331.

88. Trotti R, Rondanelli M, Cuzzoni G, Ferrari E, d'Eril GM. Circadian temporal organization of lipidic fractions in elderly people. Entrainment to the dietary schedule. Aging Clin Exp Res. 2002;14:94-99.

89. Miller M, Bachorik PS, Cloey TA. Normal variation of plasma lipoproteins: postural effects on plasma concentrations of lipids, lipoproteins, and apolipoproteins. Clin Chem. 1992;38:569-574.

90. Dominguez-Rodriguez A, Abreu-Gonzalez P, Garcia-Gonzalez M, Ferrer-Hita J, Vargas M, Reiter RJ. Elevated levels of oxidized lowdensity lipoprotein and impaired nocturnal synthesis of melatonin in patients with myocardial infarction. Atherosclerosis. 2005;180: 101-105.

91. Vijayasarathy K, Shanthi Naidu K, Sastry BK. Melatonin metabolite 6-sulfatoxymelatonin, $\mathrm{Cu} / \mathrm{Zn}$ superoxide dismutase, oxidized LDL and malondialdehyde in unstable angina. Int J Cardiol. 2010;144: 315-317.

92. Robeva R, Kirilov G, Tomova A, Kumanov P. Melatonin-insulin interactions in patients with metabolic syndrome. J Pineal Res. 2008;44: $52-56$.

93. Masue T, Wada K, Hayashi M, et al. Associations of urinary 6-sulfatoxymelatonin with biomarkers related to cardiovascular disease in Japanese women. Metabolism. 2012;61:70-75.

94. Sandyk R, Awerbuch GI. The relationship between melatonin secretion and serum cholesterol in patients with multiple sclerosis. Int JNeurosci. 1994;76:81-86.

95. Dominguez-Rodriguez A, Abreu-Gonzalez P, Reiter RJ. Melatonin and cardiovascular disease: myth or reality? Rev Esp Cardiol. 2012;65: 215-218.
ChronoPhysiology and Therapy

\section{Publish your work in this journal}

ChronoPhysiology and Therapy is an international, peer-reviewed, open access journal focusing on research into the cyclic variations and rhythmicity in physiological processes in the body and the research and development and optimal timing of administration of therapeutic targets to achieve improved outcomes and quality of life for the patient. The

\section{Dovepress}

manuscript management system is completely online and includes a very quick and fair peer-review system. Visit http://www.dovepress.com/ testimonials.php to read real quotes from published authors. 